\title{
The Chloroplast trnT-trnF Region in the Seed Plant Lineage Gnetales
}

\author{
Hyosig Won, ${ }^{1 *}$ Susanne S. Renner ${ }^{2}$ \\ ${ }^{1}$ Department of Biology, University of Missouri-St. Louis, 8001 Natural Bridge Road, St. Louis, MO 63121, USA \\ ${ }^{2}$ Missouri Botanical Garden, P.O. Box 299, St. Louis, MO 63166, USA
}

Received: 3 July 2004 / Accepted: 26 May 2005 [Reviewing Editor: Debashish Bhattacharya]

\begin{abstract}
The trnT-trnF region is located in the large single-copy region of the chloroplast genome. It consists of the $\operatorname{trn} L$ intron, a group I intron, and the $\operatorname{trn} T$ $\operatorname{trn} L$ and $\operatorname{trn} L-\operatorname{trn} F$ intergenic spacers. We analyzed the evolution of the region in the three genera of the gymnosperm lineage Gnetales (Gnetum, Welwitschia, and Ephedra), with especially dense sampling in Gnetum for which we sequenced 41 accessions, representing most of the 25-35 species. The $\operatorname{trn} L$ intron has a conserved secondary structure and contains elements that are homologous across land plants, while the spacers are so variable in length and composition that homology cannot be found even among the three genera. Palindromic sequences that form hairpin structures were detected in the $\operatorname{trn} L-\operatorname{trn} F$ spacer, but neither spacer contained promoter elements for the tRNA genes. The absence of promoters, presence of hairpin structures in the $\operatorname{trn} L-\operatorname{trn} F$ spacer, and high sequence variation in both spacers together suggest that $\operatorname{trn} T$ and $\operatorname{trn} F$ are independently transcribed. Our model for the expression and processing of the genes tRNA $^{\text {Thr }}(\mathrm{UGU})$, tRNA ${ }^{\mathrm{Leu}}(\mathrm{UAA})$, and $\mathrm{tRNA}^{\text {Phe }}$ (GAA) therefore attributes the seemingly neutral evolution of the two spacers to their escape from functional constraints.
\end{abstract}

Key words: Gymnosperms - Gnetales - $\operatorname{trn} L$ intron - trnT-trnL intergenic spacer - trn L-trnF intergenic spacer - Palindromic sequences

*Current address: Seoul National University, College of Natural Sciences, School of Biological Sciences, Seoul, Korea 151-742 Correspondence to: Susanne S. Renner, Ludwig Maximilians Universität, Systematische Botanik, Menzinger Str. 67, D-80638 München, Germany; email: renner@1rz.uni-muenchen.de

\section{Introduction}

The $\operatorname{trn} T-\operatorname{trn} F$ region is located in the large singlecopy region of the chloroplast (cp) genome. Together with its flanking genes (Fig. 1A), it forms a cistron that is conserved from mosses to seed plants (Taberlet et al. 1991). Even where chloroplast genomes have undergone extreme structural changes, such as in Pinus thunbergii (Wakasugi et al. 1994) (Fig. 1B), which has pseudogenized $n d h F$ genes located immediately downstream from the $\operatorname{trn} T-\operatorname{trn} F$ region, the region itself is conserved. Recent large-scale analyses have shown that the cistron comprised of the three tRNA genes is a uniquely shared characteristic of land plants (Quandt et al., 2004); in green algae, the trnF gene is located farther away from the other two genes. The $\operatorname{trn} T$ and $\operatorname{trn} L$ genes are lost, and the $\operatorname{trn} L_{-}^{-}$ trnF region is disrupted, in a few nonphotosynthetic flowering plants, such as Epifagus virginiana (Orobanchaceae [Wolfe et al. 1992]) (Fig. 1C).

Because of its conserved gene order, its high variability, and the adequate size of its intergenic spacer (IGS) and intron, the $\operatorname{trn} T-\operatorname{trn} F$ region is widely sequenced for phylogenetic analyses at the species and genus level in seed plants (Taberlet et al. 1991; Bakker et al. 2000; Borsch et al. 2003; Quandt et al., 2004; Shaw et al. 2005). Throughout green plants, tRNA genes are either monomeric, with putative promoter elements located upstream of the genes, or polymeric, containing other tRNAs, rRNAs, and mRNAs (Martin 1995). Examples of monomeric tRNAs are tRNA $^{\text {Ser }}$ (Gruissem et al. 1986; Wu et al. 1997) and tRNA $_{2}^{\text {Met }}$ (Gruissem and Zurawski 1985). Examples of polymeric tRNAs are tRNA ${ }^{\mathrm{Arg}}$, which is part of an operon encompassing 5'-16S-tRNA ${ }^{\text {Ile }}$-tRNA ${ }^{\text {Ala }}$-23S4.5S-5S-tRNA ${ }^{\mathrm{Arg}}-3^{\prime}$ and is located within the inverted 

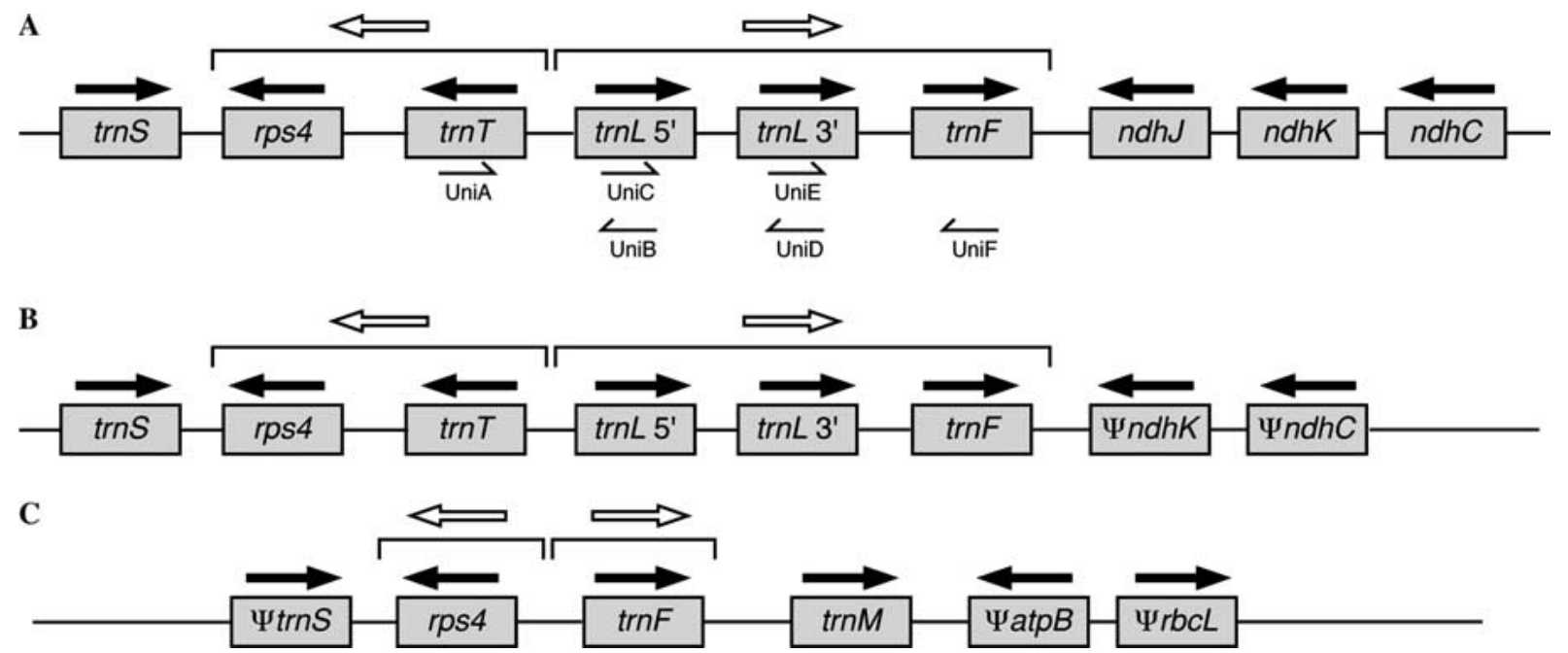

Fig. 1. Organization of the $\operatorname{trn} T-\operatorname{trn} L-\operatorname{trn} F$ cistron in the large single-copy region of the chloroplast genome. Open arrows indicate postulated directions of transcription; filled arrows, orientation of genes. Primers used to amplify the $\operatorname{trn} T-\operatorname{trn} F$ region are shown as half-arrows. A Map representing gene order in mosses, ferns, and angiosperms. Genes flanking the trnT-trnF region are conserved across Marchantia (liverwort), Anthoceros (hornwort), Psilotum (whisk fern), and the angiosperm genera Amborella, Calycanthus,

repeat region (Leal-Klevezas et al. 2000), and the trnE operon of tRNA ${ }^{\mathrm{Glu}}, \mathrm{tRNA}^{\mathrm{Tyr}}$, and tRNA ${ }^{\mathrm{Asp}}$, which is located in the large single-copy region. The transcripts of such operons are processed to release the individual tRNA molecules (Ohme et al. 1985).

Chloroplast genes, such as the tRNA genes, usually contain upstream and downstream signals facilitating their expression. Termination of transcription is signaled by hairpin structures and T-rich regions downstream of the operon (Bogorad 1991). Steinmetz et al. (1983) compared the $5^{\prime}$-flanking regions of the $\mathrm{tRNA}_{3}^{\mathrm{Ser}}, \quad \mathrm{tRNA}^{\mathrm{Phe}}, \quad \mathrm{tRNA}_{2}^{\mathrm{Thr}}, \mathrm{tRNA}_{2}^{\mathrm{Leu}}$, and tRNA Met genes and discovered nucleotide stretches that resembled the " -35 " and " -10 " promoter regions of bacterial genes, probably because of the bacterial origin of the chloroplast (see also HanleyBowdoin and Chua 1987; Bogorad 1991; Inokuchi and Yamao 1995). Analysis of these conserved regions together with ones seen in other plastid genes yields the consensus sequences ATTGANA at " -35 " and TAAGAT at "-10." A study of the function of these prokaryote-type promoter regions in $p s b A$, $r b c L$, and $a t p B$ showed that they are essential for the proper expression of these genes (Gruissem and $\mathrm{Zu}-$ rawski 1985). Other tRNA genes, however, lack prokaryote-type promoter elements and instead have internal promoter elements that are highly conserved (Galli et al. 1981; Gruissem et al. 1986; Cheng et al. 1997). Putative promoter elements upstream of trnT as well as trnF (Steinmetz et al. 1983; Kanno and Hirai 1993; van Ham et al. 1994) suggest that these genes can be expressed independently, although no experimental study has been done. Independent
Oryza sativa, Triticum aestivum, Zea mays, Lotus japonica, Spinacia oleracea, Nicotiana tabacum, Atropa belladonna, and Arabidopsis thaliana. B Map of Pinus thunbergii (black pine). Note the pseudogenized $n d h K$ and $n d h C$ and the lack of $n d h J$ compared to mosses, ferns, and angiosperms. C Map of Epifagus virginiana, a nonphotosynthetic angiosperm, modified from Wolfe et al. (1992). Note the loss of $\operatorname{trn} T$, trnL, and $n d h$ genes and the pseudogenization of $\operatorname{trn} S$, atpB, and $r b c L$.

expression is also indicated by the opposite orientation of the tRNA ${ }^{\mathrm{Thr}}(\mathrm{UGU})$ gene relative to the tRNA $^{\text {Leu }}(\mathrm{UAA})$ and tRNA ${ }^{\text {Phe }}($ GAA) genes (Figs. 1A and B). This suggests that the tRNA genes may comprise two operons, one consisting of the trnT and rps4 genes and the other of $\operatorname{trn} L$ and $\operatorname{trn} F$. Chloroplast tRNA genes or operons are transcribed with $5^{\prime}$ leader and $3^{\prime}$ trailer sequences, and the precursor-tRNAs are posttranscriptionally modified to form mature tRNAs. The processing events consist of $5^{\prime}$ end maturation, formation of a $3^{\prime}$ end, CCA addition, intron removal, and base modification (Martin 1995). The endonucleolytic cleavage of the $5^{\prime}$ leader sequence and the $3^{\prime}$ trailer sequence has been attributed, respectively, to endonucleases RNase P (Gegenheimer 1996; Frank and Pace 1998) and RNase Z (Frank and Pace 1998; Schiffer et al. 2001, 2002). The spacers are not needed for the processing of tRNAs, leading Bakker et al. (2000) to the conclusion that they may evolve neutrally. By contrast, the group I intron contained in the trn $L$ gene maintains its secondary structure and sequence elements critical for its self-splicing from precursor-RNAs (Cech 1988; Michel and Westhof 1990; Simon et al. 2003). These sequence elements are conserved from eubacteria to chloroplasts (Kuhsel et al. 1990; Xu et al. 1990; Besendahl et al. 2000).

Here we analyze the cp $\operatorname{trn} T-\operatorname{trn} F$ region in the three genera of Gnetales, an ancient lineage of seed plants for which well-supported species-level phylogenies are available (Ickert-Bond and Wojciechowski 2004; Huang et al. 2005; Won and Renner 2005a). The sequence characteristics discovered, together with the typical 
Table 1. Length variation (bp) and $\mathrm{G}+\mathrm{C}$ content (percentage) of the chloroplast $\operatorname{trn} T-\operatorname{trn} L$ IGS, $\operatorname{trn} L$ intron, and $\operatorname{trn} L-\operatorname{trn} F$ IGS in Gnetales

\begin{tabular}{llll}
\hline & trnT-trnL IGS & trnL intron & trnL-trnF IGS \\
\hline Gnetum $(n=41)$ & $292-340(30.4-34.2)$ & $329-384(34.8-39.3)$ & $132-169(33.7-45.7)$ \\
S. America & $300-304(31.9-32.6)$ & $329-379(34.8-37.5)$ & $132-169(34.3-43.9)$ \\
Africa & $292(31.2-31.5)$ & $384(34.9)$ & $165(37.0)$ \\
Asia I & $296-311(31.1-34.2)$ & $341-351(36.6-38.9)$ & $138-166(33.7-39.4)$ \\
Asia II & $296-340(30.4-32.7)$ & $332-347(36.4-39.3)$ & $133-149(40.0-45.7)$ \\
Welwitschia $(n=1)$ & $313(30.4)$ & $317(30.4)$ & $250(33.2)$ \\
Ephedra $(n=3)$ & $156(28.8)$ & $290(36.6-37.2)$ & $112^{*}(26.7)^{*}$ \\
\hline
\end{tabular}

*Based on one sequence provided by S. Ickert-Bond (pers. commun.).

function of enzymatic systems involved in cp tRNA processing, lead us to suggest a model for the expression and processing of the genes tRNA ${ }^{\mathrm{Thr}}(\mathrm{UGU})$, tRNA $^{\text {Leu }}\left(\right.$ UAA), and tRNA ${ }^{\text {Phe }}($ GAA).

\section{Materials and Methods}

\section{Taxon Sampling}

The samples, voucher information, and GenBank accession numbers obtained in this study are listed in Appendix 1 (Supplementary Material). Most samples were collected in the field by H.W., but a few are from botanical gardens or herbarium material.

\section{Gene Sequencing}

We extracted DNA from silica gel-dried leaves, using QIAGEN Plant DNeasy minikits. Concentration and quality of extracted DNAs were checked by $1 \%$ agarose gel electrophoresis with a ( $\lambda$ HindIII/EcoRI size marker. The chloroplast tRNA ${ }^{\text {Leu }}$ (UAA) intron and adjacent IGSs were amplified using primers designed by Taberlet et al. (1991) (Fig. 1 shows their placement). The PCR reaction volume was $25 \mu \mathrm{l}$ and contained $2.5 \mu \mathrm{l}$ of Taq $10 \times$ reaction buffer, $1.5 \mathrm{mM} \mathrm{MgCl} 2,0.4 \mathrm{mM}$ primer, a $0.2 \mathrm{mM}$ concentration of each dNTP, 0.625 unit of Taq DNA polymerase (Promega), and 0.5$2 \mu \mathrm{g}$ of template DNA. PCR cycles consisted of 30 cycles of 1 min at $97^{\circ} \mathrm{C}$ for template denaturation, $1 \mathrm{~min}$ at $53^{\circ} \mathrm{C}$ for primer annealing, and $1 \mathrm{~min} 20 \mathrm{~s}$ at $72^{\circ} \mathrm{C}$ for primer extension, followed by $7 \mathrm{~min}$ at $72^{\circ} \mathrm{C}$ for completion of primer extension. After electrophoresis of PCR products in $1 \%$ agarose gels, PCR products were purified with QIAquick PCR product extraction kits (QIAGEN) and directly sequenced using the ABI Prism Big Dye Terminator Cycle Sequencing Ready Reaction Kit (Perkin Elmer). Sequencing reactions were electrophoresed in an ABI 377 sequencer (Perkin Elmer). We were able to sequence/read both strands except for a stretch in the middle of the $\operatorname{trn} L-F$ spacer, where signals after the repeat of 'AT' started to overlap and fade out. This region was thus mainly read in only one direction. The same problem occurred after the 'A' and ' $\mathrm{G}$ ' repeats in the middle of the Gnetum $\operatorname{trn} L$ intron. Sequences were aligned and cleaned up using Seqman II (DNASTAR).

\section{Sequence Analysis}

We obtained 41 complete sequences from about 25 species of Gnetum, 1 sequence from Welwitschia, and 3 from Ephedra (Appendix 1, Table 1). For Ephedra, we only sequenced the trnT$\operatorname{trn} L$ IGS and the $\operatorname{trn} L$ intron. A data matrix for sequences of each chloroplast region was constructed using $\mathrm{Se}-\mathrm{Al}$ software (version 2.0a11; http://evolve.zoo.ox.ac.uk/). Length and $\mathrm{G}+\mathrm{C}$ content were calculated from the aligned sequences. Sequence divergences were calculated using Kimura's (1980) two-parameter model. Chloroplast tRNA ${ }^{\text {Leu }}(\mathrm{UAA})$ intron and adjacent IGS sequences were compared to the sequences of tRNA ${ }^{\mathrm{Leu}}(\mathrm{UGU}), \mathrm{tRNA}^{\mathrm{Thr}}$ (UAA), and tRNA ${ }^{\text {Phe }}$ (GAA) of Pinus thunbergii, the chloroplast of which has been sequenced (Wakasugi et al. 1994), to determine the boundaries of the genes, intron, and spacer. To predict the secondary structure of the region, especially of palindromic (inverted repeated) sequences found in the $\operatorname{trn} L-\operatorname{trn} F$ IGS, we used MFOLD (version 3.1; http://www.bioinfo.rpi.edu/applications/mfold/ [Zuker 2003]), which estimates the secondary structure of DNA by thermodynamics. To detect promoter elements of the tRNA genes, we examined the IGS sequences for " -35 " and " -10 " promoter element homologies. The data matrices of Borsch et al. (2003) and Quandt et al. (2004), which comprise $\operatorname{trn} L$ intron and spacer sequences of numerous land plants, were also compared to that of the Gnetales sequenced here.

\section{Phylogenetic Analysis}

The flanking spacers of the tRNA ${ }^{\text {Leu }}$ gene showed sufficient variation in length among the three genera to make alignment difficult (see Results). We therefore designated the South American Gnetum group as a functional outgroup for the intra-Gnetum analysis, based on results of a phylogenetic analysis of Gnetales $r b c L$ and $m a t K$ sequences (Won and Renner 2003). We used PAUP* $4.0 \mathrm{~b} 10$ (Swofford 2002) and Mr. Bayes (version 3.0b4 [Huelsenbeck and Ronquist 2001]) for phylogenetic analyses. The data matrix of the $\operatorname{trn} L$ intron and $\operatorname{trn} T-\operatorname{trn} L$ and $\operatorname{trn} L-\operatorname{trn} F$ spacers was analyzed by parsimony, neighbor-joining, and Bayesian inference. Parsimony analyses were run using heuristic searching, with 100 random taxon-addition replicates, holding 100 trees at each step, treebisection-reconnection (TBR) branch swapping, the MulTrees, Collapse, and Steepest Descent options, and no upper limit for trees held in memory. Neighbor joining used K-2-P distances and ignored gaps. Bayesian probabilities were obtained under the GTR $+\gamma+$ Pinv model, with four Markov chain Monte Carlo chains run for 3 million generations, using random trees as starting point, and sampling every 10,000th generation. The trees sampled before the saturation of maximum likelihood estimates were discarded as burn-in. Nonparametric bootstrap support for parsimony and neighbor joining was obtained by resampling the data 1000 times with the same search options and model.

\section{Results}

\section{Length and $G+C$ Contents}

The length of the $\operatorname{trn} L$ intron was 319-384 bp; that of the trnT-trnL spacer, 292-340 bp; and that of the trnL-trnF spacer, 132-169 bp (Table 1). These sizes are similar to Welwitschia $(317,313$, and $250 \mathrm{bp})$ but 


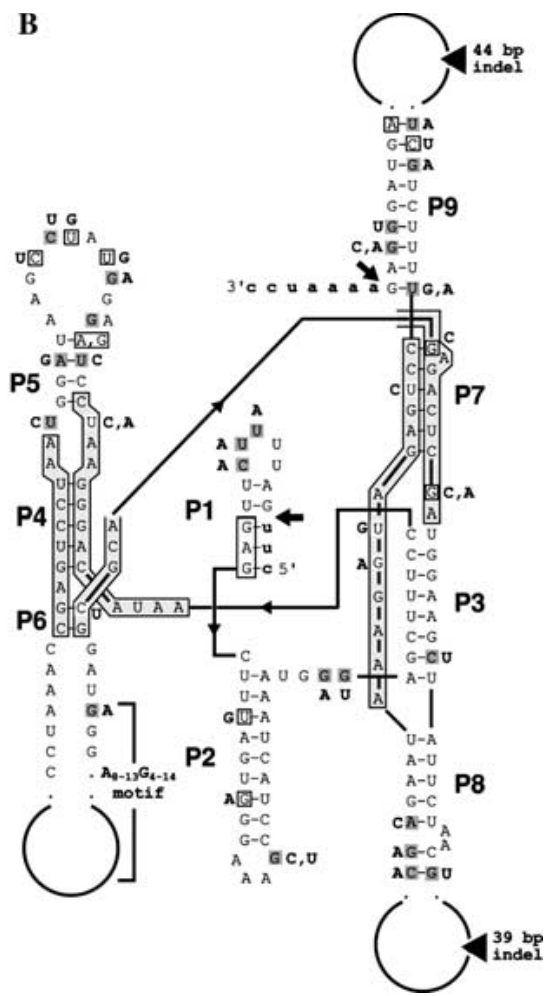

Fig. 2. A Sequence alignment of the chloroplast $t R N A^{\text {Leu }}(\mathrm{UAA})$ gene and intron (a group I intron). Open boxes indicate the tRNA ${ }^{\text {Leu }} 5^{\prime}$ and $3^{\prime}$ coding regions and shaded boxes indicate conserved sequence elements $(\mathrm{P}, \mathrm{Q}, \mathrm{R}, \mathrm{S})$ in the intron. Nine stem-andloop structures (P1-P9) are marked by brackets. See Cech (1988) for the secondary structure nomenclature of group I introns. Sequences shown are those of Gnetum africanum, Welwitschia mirabilis, and Ephedra trifurca. B Secondary structure model of the

significantly longer than Ephedra (290, 156, and 112 $\mathrm{bp}$ ), especially in the trnT-trnL spacer. Of the multiple accessions of Gnetum, only the four of G. gnemon showed distinct variation in length (one was excluded from the data matrix). Two of them, Suksathan s.n. and RBGE19480112, had shorter spacer sequences due to autapomorphic gaps at base positions $355-365$ of the trnT-trnL spacer and positions 1104-1113 of the trnL-trnF spacer compared to the other two accessions, Won 514 and Won 568.

$\mathrm{G}+\mathrm{C}$ contents of the $\operatorname{trn} L$ intron and spacers showed opposite trends among the three genera (Table 1). In the trnL intron, Gnetum had a higher $\mathrm{G}+\mathrm{C}$ content than Welwitschia $(34.8-39.3 \%$ vs. $30.4 \%$ ) but was similar to Ephedra (36.6-37.2\%). In the $\operatorname{trn} T-\operatorname{trn} L$ and $\operatorname{trn} L-\operatorname{trn} F$ spacers, Gnetum was comparable to Welwitschia (30.4-34.2\% vs. $30.4 \%$ and $33.7-45.7 \%$ vs. $33.2 \%$, respectively) but had a higher $\mathrm{G}+\mathrm{C}$ content than Ephedra (30.4-34.2\% vs. $28.8 \%$ and $33.7-45.7 \%$ vs. $26.7 \%$, respectively).

\section{Sequence Comparison, Alignment, and Divergence}

Due to the large length and sequence variation, we could not align the spacer sequences of three genera, chloroplast $\operatorname{trnL}$ intron in Gnetales. Intron splicing sites are marked with two arrows. Locations of the $\mathrm{A}_{8-13} \mathrm{G}_{4-14}$ motif in the P6 element, the 39-bp indel in the P8 element, and the 44-bp indel in the P9 element of Gnetum are indicated. Boxed bases indicate variation within Gnetum; shaded bases, variation among the three genera of Gnetales. Variable bases are in boldface. The secondary structure model is modified from Cech et al. (1994) and Quandt et al. (2004)

nor could we find homologous motifs in their spacer regions. Like Borsch et al. (2003) and Quandt et al. (2004), we failed to detect specific homologies of Gnetales with other seed plant sequences. The trnL intron sequences, by contrast, contained several highly conserved motifs (Fig. 2), especially the P, Q, $\mathrm{R}$, and $\mathrm{S}$ sequence elements and the $\mathrm{P} 1, \mathrm{P} 2$, and $\mathrm{P} 3$ elements (Figs. 2 and 3A). The P5, P6, P8, and P9 structural elements were variable. Comparison of gnetalean sequences with those of other land plants also revealed the expected conserved tRNA ${ }^{\text {Leu }}$ group I intron structure. By comparing our data matrix with the basal angiosperm matrix of Borsch et al. (2003), we detected a highly conserved "-35"-like element (TTGACA) and "-10"-like element (TAGGAT) between base positions -45 and -16 in the upstream of the tRNA ${ }^{\text {Phe }}$ gene. However, we could not detect any promoter elements in the $\operatorname{trn} T-\operatorname{trn} L$ or $\operatorname{trn} L-\operatorname{trn} F$ spacer regions of Gnetales.

Alignment of the trnL intron and IGSs of Gnetum required 1-, 4-, 5-, 6-, 8-, 9-, 10-, 15-, 39-, 40-, and 44bp-long noninformative indels and 11 informative indels (Appendix 2). The P8 and P9 structural elements of G. paniculatum and G. africanum contained 39- and 44-bp-long indels (Fig. 2B), and the $\operatorname{trnT}$ - 


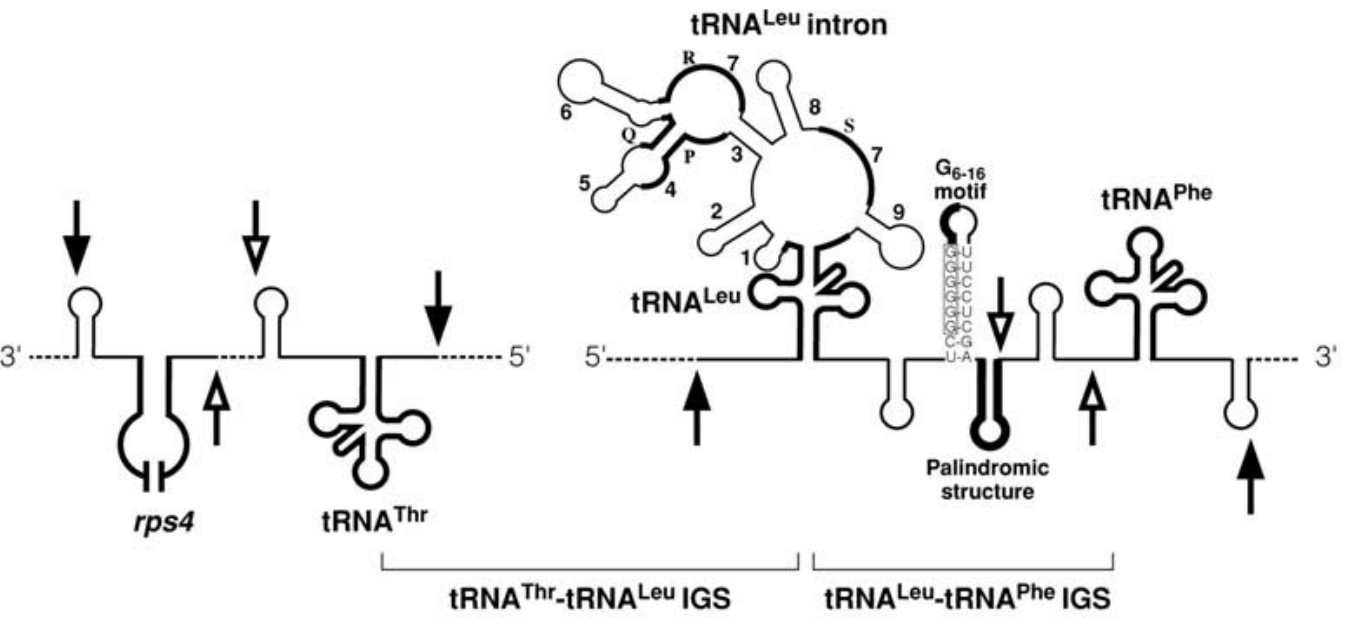

\section{B}

3'

3'

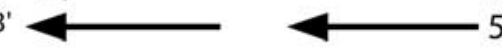

$5^{\prime}$ a. Cotranscription

$5^{\prime}$ b. Independent transcription

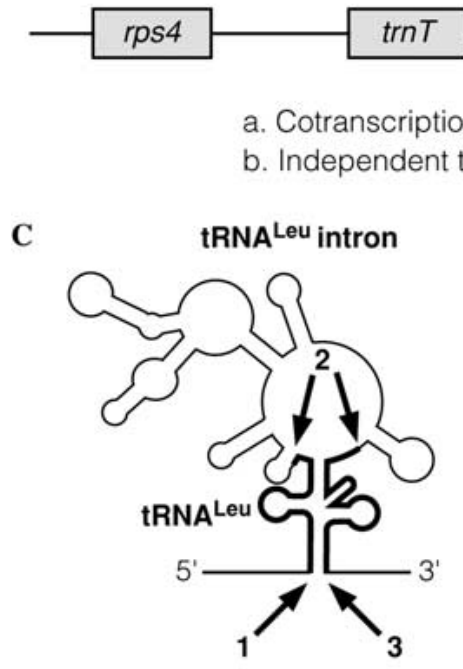

1. $5^{\prime}$ maturation

2. Intron splicing

3. 3' maturation

4. CCA addition

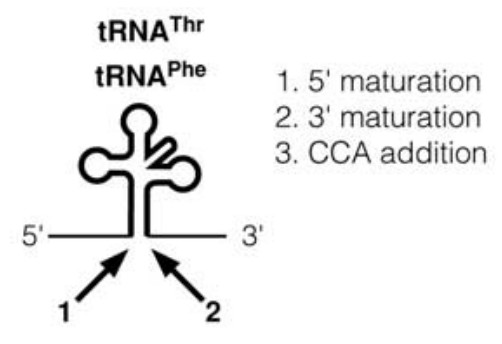

termination/start points for the independent transcription model. The secondary structure model for $\operatorname{trn} L$ intron is modified from that of Kuhsel et al. (1990). The structure of the rps4 gene is arbitrary. B Proposed transcription of Gnetum trnT, $\operatorname{trn} L$, and $\operatorname{trn} F$ genes. TrnT and $r p s 4$ are transcribed in the opposite direction from $\operatorname{trn} L$ and $t r n F$. Both $\operatorname{trn} T$ and $r p s 4$, and $\operatorname{trn} L$ and $\operatorname{trnF}$, could be cotranscribed or independently transcribed. C Proposed order of tRNA processing.

\section{Palindromic Structures in the trnL-trnF IGS Region}

The palindromic sequences in the $\operatorname{trn} L-\operatorname{trn} F$ spacer were first identified by sequence comparison and then verified by looking at the secondary structure predicted by MFOLD. They are listed in Table 2. Palindromes were found in all Gnetum sequences. They formed hairpin structures, with tandem repeats of 'AT' making up the stem of the hairpin (Fig. 3A). The secondary structure of the $\operatorname{trn} L-\operatorname{trn} F$ spacer suggests that the $\mathrm{G}_{6-}$ ${ }_{16}$ motif is also involved in a conserved hairpin immediately upstream of the palindromic sequences, with

Sequence divergences among the gnetalean genera and among Gnetum species are specified in Appendix 3. 
Table 2. Palindromic sequences in the Gnetum chloroplast tRNA ${ }^{\text {Leu }}$-tRNA ${ }^{\text {Phe }}$ IGS region

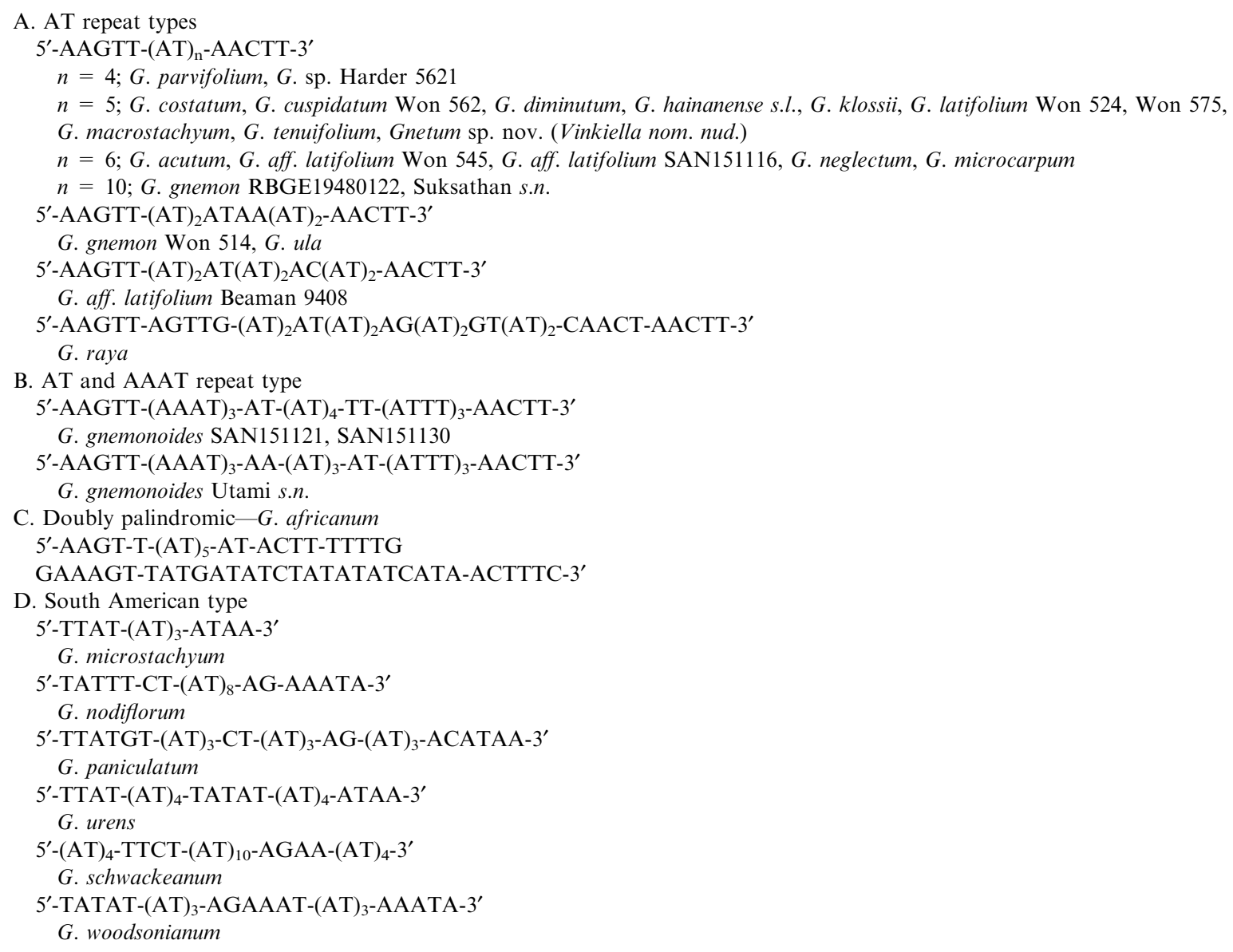

UCGGGGGG//AGCUCCUU forming a stem (Fig. 3A). Prediction of the secondary structure of the Welwitschia trnL-trnF spacer detected several hairpins, although the sequence itself does not have palindromic sequences. Palindromic structures found in Gnetum coincided with geographical clades; Asian and African palindromic sequences started with AAGTT and ended in AACTT, which form a stem by complementary base-pairing. The AAGTT motif was conserved throughout Gnetum, while the AACTT motif was absent from the South American species (Table 2; Fig. 4, gap I). However, although the AAGTT motif was present in South America, it was not involved in hairpin formation there. Asian species had AT repeats except for G. gnemonoides, which had AT plus AAAT repeats, perhaps as a result of mutation from ATAT, with compensatory downstream changes of ATAT to ATTT. Gnetum africanum had two consecutive palindromic structures, referred to as "doubly palindromic" in Table 2, separated by five bases (TTTTG). The length of the palindromes 5'-AAGTT-(AT) ${ }_{n}$-AACTT$3^{\prime}$ ranged from $18 \mathrm{bp}(n=4)$ to $30 \mathrm{bp}(n=10)$, and there were several cases with substitutions in the AT repeats (Table 2). The C's and G's in the middle of AT repeats of the South American and African sequences probably result from compensatory base changes in the stem region of hairpin structures.

\section{Phylogenetic Analyses}

Alignment of chloroplast trnL intron and adjacent spacer sequences required 1 to $44 \mathrm{bp}$ indels as described above; number of aligned characters, parsimony-informative sites, and gaps are shown in Table 3, and the data file has been submitted to TreeBase. Sequences of Gnetum could not be aligned with those of Welwitschia and Ephedra except in the $\operatorname{trn} L$ intron region (Fig. 2). One of the tree topologies estimated by Bayesian analysis (in four repeat runs) of the complete intron and spacer sequences is shown in Fig. 4. Parsimony analysis yielded 71 trees on three islands. Accessions sorted geographically into a South American clade, an African clade, and two Asian clades (labeled Asia I and Asia II in Fig. 4) that were well supported except for the monophyly of the Asian group. Within the Asia II clade, two subclades were resolved, a G. cuspidatum clade and a G. hainanense s.l. clade (Fig. 4). Except for two homoplasious gaps marked A and G in Fig. 4, gaps (B$\mathrm{K})$ were informative. A neighbor-joining tree from 


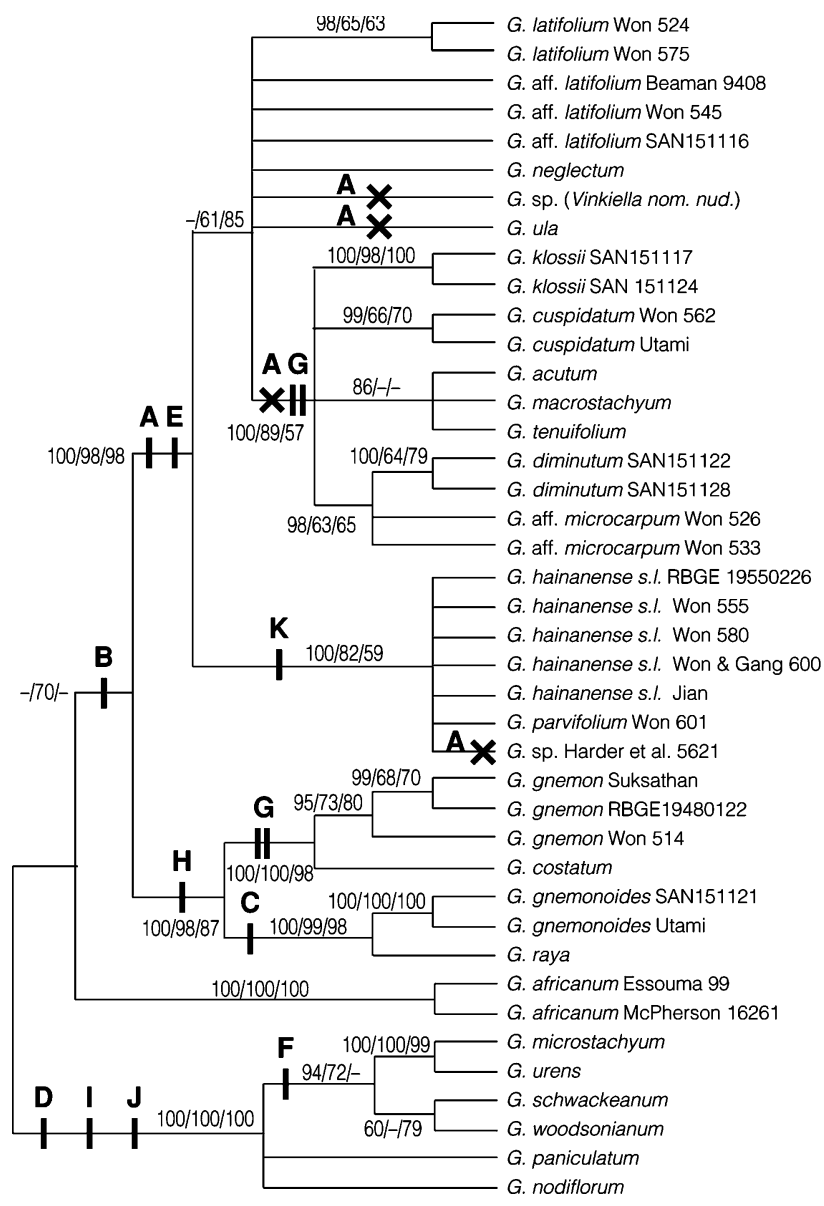

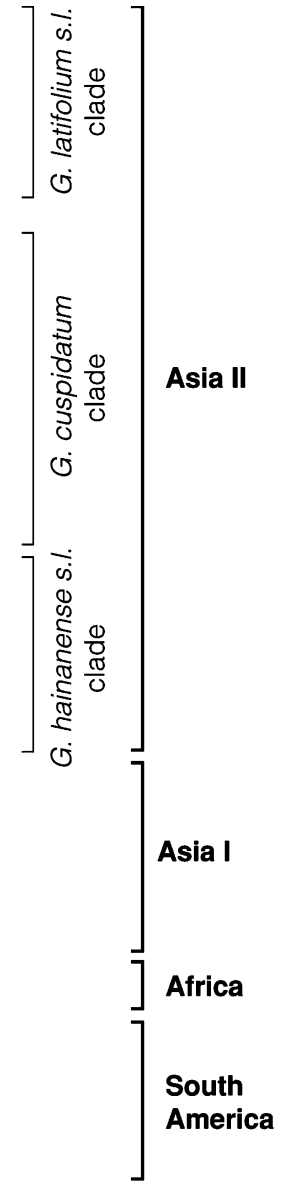

Fig. 4. Phylogeny of Gnetum obtained from Bayesian analysis of the chloroplast $\operatorname{trn} L$ intron and spacer sequences. Values next to nodes are Bayesian posterior probabilities, followed by bootstrap values under parsimony $(\mathrm{CI}=0.55, \mathrm{RI}=0.45$, excluding uninformative characters) and neighbor joining. Base positions 142-181, 246-260, 297-301, 576-606, 706-745, 810$853,976-993$, and 1012-1070 were excluded from the analyses and 11 informative gaps $(\mathrm{A}-\mathrm{K})$ were binary-coded (see Appendix 2).

Table 3. Number of characters, parsimony-informative sites, and phylogenetically informative indels in the chloroplast tRNA ${ }^{\text {Leu }}$ intron and intergenic spacers in Gnetum

\begin{tabular}{llll}
\hline & trnT-trnL IGS & trnL intron & trnL-trnF IGS \\
\hline Aligned characters & 371 & 436 & 189 \\
Parsimony-informative sites & $46(12.4 \%)$ & $33(7.6 \%)$ & $46(24.3 \%)$ \\
Informative sites after excluding gaps & $45(12.1 \%)$ & $26(6.0 \%)$ & $18(9.5 \%)$ \\
Phylogenetically informative indels & 5 & 3 & 3 \\
\hline
\end{tabular}

just the $\operatorname{trn} L$ intron sequences also identified the South American species as the basal branch and sister to the Asian and African clades (data not shown).

\section{Discussion}

\section{Behavior of the trnL Intron and Adjacent Spacers in Gnetum}

Topologies obtained from the $\operatorname{trn} L$ sequences were congruent with phylogenies from separate and combined analyses of nuclear sequences (rRNA Internal Transcribed Spacer [ITS] and the second intron of $L E A F Y$ ), chloroplast mat $K$ and $r b c L$ genes, and the conserved region of the mitochondrial nadl second intron and partial exon sequences (Won and Renner $2005 \mathrm{a}, \mathrm{b})$. This is in agreement with other studies that show that fast evolving regions can sometimes provide cost-efficient phylogeny reconstruction even of deep divergences (Hershkowitz and Lewis 1996; Källersjö et al. 1998; Borsch et al. 2003; Hilu et al. 2003; Quandt et al. 2004). Based on fossil-calibrated molecular clocks, the split between Gnetum and Welwitschia had already occurred by 115 million years ago (Won and Renner 2003). This great age partly explains the high sequence variation in the two spacers; in addition, the absence of conserved promoter elements for tRNA genes from both spacers suggests that neither is under functional constraints as suggested earlier for the trnL-trnF spacer but not the trnT-trnL spacer (Bakker et al. 2000; Quandt et al. 2004).

We found several palindromes in the Gnetum $\operatorname{trn} L-\operatorname{trn} F$ IGS region (Table 2). These sequences were involved in hairpin formation by intrastrand 
base-pairing. In addition, two more hairpin structures were commonly formed between the $3^{\prime}$ end of the tRNA ${ }^{\mathrm{Leu}}$ gene and the palindromic structure (Fig. 3A). Such stem-and-loop structures can be substrates for structure-specific nucleases and/or mismatch repair enzymes (Leach 1994) and can cause double-strand breakage during DNA replication (Nasar et al. 2000). Slippage during replication is also the likely cause of the many 'A,' 'G,' and 'AT' repeats in the intron and spacer regions (Levinson and Gutman 1987; Kelchner 2000; Graham et al. 2000). So far, no enzymes that would recognize the hairpin structures in the tRNA spacers have been reported. Instead, the enzymes that process precursor tRNAs, such as RNase P, RNase Z, and ATP (CTP):tRNA nucleotidyl transferase, recognize only the tRNA's tertiary structure (Martin 1995; Frank and Pace 1998; Kunzmann et al. 1998; Schiffer et al. 2002), suggesting that the nucleotide sequence between the tRNA genes may be almost irrelevant to tRNA enzymatic maturation. Circumstantial evidence, however, indicates that the palindromes in the $\operatorname{trn} L-\operatorname{trn} F$ spacer serve two functions: By forming thermodynamically stable hairpins, they may reduce the chance that stem-loops interfere with tertiary structure formation of adjacent tRNAs. By forming hairpin structures, they may also function as transcription termination signals as has been found in operons originating from bacteria, including chloroplast operons (Bogorad 1991). Hairpin structures/inverted repeated sequences have been reported from the downstream of maize tRNA $^{\mathrm{His}}(\mathrm{GUG})$ (Schwarz et al. 1981) and tRNA ${ }^{\text {Phe }}$ (UGU) (Steinmetz et al. 1983), spinach tRNA ${ }^{\text {Ser }}$ (UGA) (Holschuh et al. 1984), tobacco tRNA ${ }^{\text {Glu }}$ (UUC)-tRNA ${ }^{\text {Tyr }}$ (GUA)-tRNA ${ }^{\text {Asp }}$ (GUC) (Ohme et al. 1985), and the Brassica napus rRNAs-tRNA ${ }^{\text {Arg }}$ (ACG) operon (Leal-Klevezas et al. 2000).

In many seed plants, the $\operatorname{trn} L-\operatorname{trn} F$ spacer appears to harbor a bacterial-type promoter for the tRNA ${ }^{\text {Phe }}$ gene (Steinmetz et al. 1983). Indeed, we detected the " -35 " and " -10 " promoters in several conifers and basal angiosperms, and Quandt et al. (2004) found them in most land plant lineages except lycophytes and leptosporangiate ferns. In Gnetales, however, we detected no promoters in either of the two spacers. Studies on the function of tRNA upstream sequences have shown that either they contain prokaryote-type promoters (Gruissem et al. 1983; Steinmetz et al. 1983; Wu et al. 1997) or there are eukaryote-type internal promoters directly in the tRNA (Galli et al. 1981; Gruissem et al. 1986; Cheng et al. 1997). The loss of promoter elements from the nonphotosynthetic Epifagus tRNA ${ }^{\mathrm{Glu}}$ (UUC) (Morden et al. 1991) suggests, however, that prokaryote-type promoters are not always required for transcription of tRNA genes, and a few studies of tRNA transcription in lineages with functioning chloroplasts also suggest this (Gruissem et al. 1986; Jahn 1992; Wu et al. 1997). We therefore interpret the lack of promoter elements in the upstream regions of Gnetales $\mathrm{tRNA}^{\mathrm{Thr}}$, tRNA $^{\text {Leu }}$, and tRNA ${ }^{\text {Phe }}$ genes as indicating that these genes have internal promoters, relieving their spacer regions from functional constraints that would come from harboring functional promoters. Release from involvement in the tRNA promoting/processing mechanism may explain why the $\operatorname{trn} T-\operatorname{trn} L$ and $\operatorname{trn} L-$ trnF intergenic spacers contain so many point mutations and indels.

In contrast to the two spacers, the trnL intron maintains highly conserved structural motifs that allow it to form the characteristic secondary structure of group I introns of land plants (Kuhsel et al. 1990; Xu et al. 1990; Lambowitz et al. 1999; Belfort et al. 2002; Quandt et al., 2004) (Fig. 2). Unlike the self-splicing introns of Anabaena and Tetrahymena (Zaug et al. 1993), chloroplast trnL introns of land plants require helper proteins for splicing (Xu et al. 1990; Lambowitz et al. 1999; Simon et al. 2003), in this regard resembling group II introns in tRNA genes (Vogel et al. 1999). The three gaps that we detected in the $\operatorname{trn} L$ intron all belonged to the $\mathrm{P} 8$ stem-and-loop, one of the autapomorphic indels also belonged to the $\mathrm{P} 8$ element, and another occurred in the P9 element. Borsch et al. (2003) similarly found that $68 \%$ of the characters in their basal angiosperm trnL intron matrix were contributed by the P6 and P8 stem-loops, while the P, Q, $\mathrm{R}$, and $\mathrm{S}$ structural elements were highly conserved.

\section{Expression and Processing of the cp $t R N A^{T h r}$,} tRNA $A^{\text {Leu }}$, and $t R N A^{\text {Phe Genes: A Model }}$

Based on our results, the secondary structure of the $\mathrm{cp}$ $\operatorname{trn} T-\operatorname{trn} F$ region is as shown in Fig. 3A. As discussed above and shown in Figs. 1A and B and Fig. 3, the cp tRNA $^{\text {Thr }}$ gene and the tRNA ${ }^{\text {Leu }}-$ tRNA $^{\text {Phe }}$ genes are transcribed in opposite directions. Two earlier studies have presented indirect evidence for cotranscription of the tRNA ${ }^{\mathrm{Leu}}$ and tRNA ${ }^{\text {Phe }}$ genes: Bonnard et al. (1984) saw the absence of a termination signal in the Vicia faba trnL-trnF spacer as such evidence, and Koch et al. (2005) the presence of duplicated tRNA ${ }^{\text {Phe }}$ genes between the two bacterial promoter elements present in the Brassicaceae they studied. However, the structural aspects of the $\operatorname{trn} L-t r n F$ spacer in Gnetum, especially the presence of palindromic sequences and hairpin structures, favor an interpretation of independent transcription (previous section). Regardless of whether tRNA cistrons or operons including tRNA(s) are cotranscribed or independently transcribed, the processing machinery of the chloroplast has to successfully mature each tRNA (Steinmetz et al. 1983; Ohme et al. 1985; Marion-Poll et al. 1988; Christopher and Hallick 1990; Tonkyn and Gruissem 1993; Leal-Klevezas et al. 2000). The tRNA process- 
ing pathway includes (1) $5^{\prime}$ end maturation by excision of $5^{\prime}$ leader sequence by RNase P, (2) splicing of the $\operatorname{trnL}$ intron (group I intron), (3) excision of the $3^{\prime}$ trailer sequence by RNase Z, (4) terminal 'CAA' addition by ATP (CTP):tRNA nucleotidyl transferase, and (5) RNA editing. The order of steps 1, 2, and 3 in the processing of the tRNA ${ }^{\text {Leu }}$ gene has not been studied, but the splicing of group II introns in the tRNA ${ }^{\mathrm{Ile}}(\mathrm{GAU})$, tRNA ${ }^{\mathrm{Val}}(\mathrm{UAC})$, tRNA ${ }^{\mathrm{Ala}}(\mathrm{UGC})$, and tRNA ${ }^{\mathrm{Gly}}$ (UCC) genes indicates that $5^{\prime}$ endonucleolytic cleavage precedes intron splicing and $3^{\prime}$ end maturation (Vogel and Hesse 2001; but see Delp et al. 1991). Because group I and II intron splicing mechanisms in plant chloroplasts have common features, such as mediation by intron RNA and a requirement for helper proteins (Belfort et al. 2002) or chloroplast ribonucleoproteins (cpRNPs [Nakamura et al. 1999]), it is likely that processing of the tRNA ${ }^{\text {Leu }}$ gene also follows the above pathway. In tRNAs without introns, $5^{\prime}$ maturation also usually precedes $3^{\prime}$ maturation (Wang et al. 1988; Martin 1995; Gegenheimer 1996). The processing and splicing pathway proposed here for the $\mathrm{cp} \operatorname{trn} \mathrm{L}$ intron now needs to be tested via experiments and comparison across a much broader taxonomic range.

Acknowledgments. This paper represents a portion of a dissertation submitted by the first author in partial fulfillment of the requirements for a Ph.D. from University of Missouri-St. Louis. Financial support from the American Society of Plant Taxonomy, the International Association of Plant Taxonomy, and the International Center for Tropical Ecology at the University of Missouri-St. Louis is gratefully acknowledged.

\section{References}

Bakker FT, Culham A, Gomez-Martinez R, Carvalho J, Compton J, Dawtrey R, Gibby M (2000) Patterns of nucleotide substitution in angiosperm cpDNA trnL (UAA)-trnF (GAA) regions. Mol Biol Evol 17:1146-1155

Belfort M, Derbyshire V, Parker MM, Cousineau B, Lambowitz AM (2002) Mobile introns: pathways and proteins. In: Craig NL, Craigie R, Gellert M, Lambowitz AM (eds) Mobile DNA II. ASM Press, Washington, DC, pp 761-783

Besendahl A, Qiu Y-L, Lee J, Palmer JD, Bhattacharya D (2000) The cyanobacterial origin and vertical transmission of the plastid tRNA $^{\text {Leu }}$ group-I intron. Curr Genet 37:12-23

Bogorad L (1991) Replication and transcription of plastid DNA. In: Bogorad L, Vasil IK (eds) The molecular biology of plastids: Cell culture and somatic cell genetics of plants, Vol. 7A. Academic Press, San Diego, pp 93-124

Bonnard G, Michel F, Weil JH, Steinmetz AA (1984) Nucleotide sequence of the split tRNA ${ }^{\text {Leu }}$ gene from Vicia faba chloroplasts: evidence for structural homologies of the chloroplast tRNA ${ }^{\text {Leu }}$ intron with the intron from the autosplicable Tetrahymena ribosomal RNA precursor. Mol Gen Genet 194:330-336

Borsch T, Hilu KW, Quandt D, Wilde V, Neihuis C, Barthlott W (2003) Noncoding plastid trnT-trnF sequences reveal a well resolved phylogeny of basal angiosperms. J Evol Biol 16:558-576
Cech TR (1988) Conserved sequences and structures of group I introns: building an active site for RNA catalysis - a review. Gene 73:259-271

Cech TR, Damberger SH, Gutell RR (1994) Representation of the secondary and tertiary structure of group I introns. Nature Struct Biol 1:273-280

Cheng YS, Lin C-H, Chen L-J (1997) Transcription and processing of the gene for spinach chloroplast threonine tRNA in a homologous in vitro system. Biochem Biophys Res Comm 233:380-385

Christopher DA, Hallick RB (1990) Complex RNA maturation pathway for a chloroplast ribosomal protein operon with an internal tRNA cistron. Plant Cell 2:659-671

Delp G, Igloi GL, Kössel H (1991) Identification of in vivo processing intermediates and of splice junctions of tRNAs from maize chloroplasts by amplification with the polymerase chain reaction. Nucleic Acids Res 19:713-716

Frank DN, Pace NR (1998) Ribonuclease P: unity and diversity in a tRNA processing ribozyme. Annu Rev Biochem 67:153-180

Galli G, Hofstetter H, Birnstiel ML (1981) Two conserved sequence blocks within eukaryotic tRNA genes are major promoter elements. Nature 294:626-631

Gegenheimer P (1996) Structure, mechanism, and evolution of chloroplast transfer RNA processing systems. Mol Biol Rep 22:147-150

Graham SW, Reeves PA, Burns ACE, Olmstead RG (2000) Microstructural changes in noncoding chloroplast DNA: interpretation, evolution, and utility of indels and inversions in basal angiosperm phylogenetic inference. Int J Plant Sci 161 (Suppl 6):S83-S96

Gruissem W, Zurawski G (1985) Identification and mutational analysis of the promoter for a spinach chloroplast transfer RNA gene. EMBO J 4:1637-1644

Gruissem W, Greenberg BM, Zurawski G, Prescott DM, Hallick RB (1983) Biosynthesis of chloroplast transfer RNA in a spinach chloroplast transcription system. Cell 35:815-828

Gruissem W, Elsner-Menzel C, Latshaw S, Narita JO, Schaffer MA, Zurawski G (1986) A subpopulation of spinach chloroplast tRNA genes does not require upstream promoter elements for transcription. Nucleic Acids Res 14:7541-7556

Hanley-Bowdoin L, Chua N-H (1987) Chloroplast promoters. Trends Biochem 12:67-70

Hilu KW, Borsch T, Müller K, Soltis DE, Soltis PS, Savolainen V, Chase MW, Powell MP, Alice LA, Evans R, Sauquet H, Neinhuis C, Slotta TAB, Rohwer JG, Campbell CS, Chatrou LW (2003) Angiosperm phylogeny based on matK sequence information. Am J Bot 90:1758-1776

Holschuh K, Bottomley W, Whitfeld PR (1984) Structure of the spinach chloroplast genes for the D2 and $44 \mathrm{Kd}$ reaction-center proteins of photosystem II and for tRNA ${ }^{\text {Ser }}$ (UGA). Nucleic Acids Res 12:8819-8834

Huang J, Giannasi DE, Price RA (2005) Phylogenetic relationships in Ephedra (Ephedraceae) inferred from chloroplast and nuclear DNA sequences. Mol Phylogenet Evol 35:48-59

Huelsenbeck JP, Ronquist FR (2001) MrBayes: Bayesian inference of phylogenetic trees. Bioinformatics 17:754-755

Ickert-Bond SM, Wojciechowski MF (2004) Phylogenetic relationships in Ephedra (Gnetales): evidence from nuclear and chloroplast DNA sequence data. Syst Bot 29:834-849

Inokuchi H, Yamao F (1995) Structure and expression of prokaryotic tRNA genes. In: Söll D, RajBahndary U (eds) tRNA: Structure, biogenesis, and function. ASM Press, Washington, DC, pp 17-30

Jahn D (1992) Expression of the Chlamydomonas reinhardtii chloroplast tRNAGlu gene in a homologous in vitro transcription system is independent of upstream promoter elements. Arch Biochem Biophys 298:505-513 
Källersjö M, Farris JS, Chase MW, Bremer B, Fay MF, Humphries CJ, Petersen G, Seberg O, Bremer K (1998) Simultaneous parsimony jackknife analysis of $2538 \mathrm{rbcL}$ DNA sequences reveals support for major clades of green plants, land plants, seed plants, and flowering plants. Pl Syst Evol 213:259-287

Kanno A, Hirai A (1993) A transcription map of the chloroplast genome from rice (Oryza sativa). Curr Genet 23:166-174

Kelchner SA (2000) The evolution of non-coding chloroplast DNA and its application in plant systematics. Ann Mo Bot Gard $87: 482-498$

Kimura M (1980) A simple method for estimating evolutionary rates of base substitutions through comparative studies of nucleotide sequences. J Mol Evol 16:111-120

Koch MA, Dobes C, Matschinger M, Bleeker W, Vogel J, Kiefer M, Mitchell-Olds T (2005) Evolution of the $\operatorname{trnF}(\mathrm{GAA})$ gene in Arabidopsis relatives and the Brassicaceae family: monophyletic origin and subsequent diversification of a plastidic pseudogene. Mol Biol Evol 22:1032-1043

Kuhsel MG, Strickland R, Palmer JD (1990) An acient group I intron shared by Eubacteria and chloroplasts. Science 250:1570-1573

Kunzmann A, Brennicke A, Marchfelder A (1998) 5' end maturation and RNA editing have to precede tRNA $3^{\prime}$ processing in plant mitochondria. Proc Natl Acad Sci USA 95:108-113

Lambowitz AM, Caprara MG, Zimmerly S, Perlman PS (1999) Group I and group II ribozymes as RNPs: clues to the past and guides to the future. In: Gesteland RF, Cech TR, Atkins JF (eds) The RNA world, 2nd ed. The world of modern RNA suggests a prebiotic RNA. Cold Spring Harbor Laboratory Press, Cold Spring Harbor, NY, pp 451-485

Leach DRF (1994) Long DNA palindromes, cruciform structures, genetic instability and secondary structure repair. Bioessays 16:893-900

Leal-Klevezas DS, Martínez-Soriano JP, Nazar RN (2000) Cotranscription of 5S rRNA-tRNA ${ }^{\mathrm{Arg}}$ (ACG) from Brassica napus chloroplast and processing of their intergenic spacer. Gene 253:303-311

Levinson G, Gutman GA (1987) Slipped-strand mispairing: a major mechanism for DNA sequence evolution. Mol Biol Evol 4:203-221

Marion-Poll A, Hibbert CS, Radebaugh CA, Hallick RB (1988) Processing of mono-, di-and tricistronic transfer RNA precursors in a spinach or pea chloroplast soluble extract. Plant Mol Biol 11:45-56

Martin NC (1995) Organellar tRNAs: Biosynthesis and function. In: Söll D, RajBahndary U (eds) tRNA: Structure, biogenesis, and function. ASM Press, Washington, DC, pp 127-140

Michel F, Westhof E (1990) Modeling of the three-dimensional architecture of group I catalytic introns based on comparative sequence analysis. J Mol Biol 216:585-610

Morden CW, Wolfe KH, dePamphilis CW, Palmer JD (1991) Plastid translation and transcription genes in a non-photosynthetic plant: intact, missing and pseudo genes. EMBO J 10:3281-3288

Nakamura T, Ohta M, Sugiura M, Sugita M (1999) Chloroplast ribonucleoproteins are associated with both mRNAs and intron containing precursor tRNAs. FEBS Lett 460:437-441

Nasar F, Jankowski C, Nag DK (2000) Long palindromic sequences induce double-strand beaks during meiosis in yeast. Mol Cell Biol 20:3449-3458

Ohme M, Kamogashira T, Sinozaki K, Sugiura M (1985) Structure and cotranscription of tobacco chloroplast genes for tRNA ${ }^{\text {Glu }}$ (UUC), tRNA ${ }^{\text {Tyr }}\left(\right.$ GUA), and tRNA ${ }^{\text {Asp }}$ (GUC). Nucleic Acids Res 13:1045-1056

Quandt D, Müller K, Stech M, Hilu KW, Frey W, Frahm J-P, Borsch T (2004) Molecular evolution of the chloroplast trnL-F region in land plants. Monogr Syst Bot Mo Bot Gard 98:13-37
Schiffer S, Helm M, Théobald-Dietrich A, Giegé R, Marchfelder A (2001) The plant tRNA $3^{\prime}$ processing enzyme has a broad substrate spectrum. Biochemistry 40:8264-8272

Schiffer S, Rösch S, Marchfelder A (2002) Assigning a function to a conserved group of proteins: the tRNA $3^{\prime}$-processing enzyme. EMBO J 21:2769-2777

Schwarz Z, Jolly SO, Steinmetz AA, Bogorad L (1981) Overlapping divergent genes in the maize chloroplast chromosome and in vitro transcription of the gene for tRNA ${ }^{\text {His }}$. Proc Natl Acad Sci USA 78:3423-3427

Shaw J, Lickey EB, Beck JT, Farmer SB, Liu W, Miller J, Siripun KC, Winder CT, Schilling EE, Small RL (2005) The tortoise and the hare II: Relative utility of 21 noncoding chloroplast DNA sequences for phylogenetic analysis. Am J Bot 92:142-166

Simon D, Fewer D, Friedl T, Bhattacharya D (2003) Phylogeny and self-splicing ability of the plastid tRNA-Leu group I intron. J Mol Evol 57:710-720

Steinmetz AA, Krebbers ET, Schwarz Z, Gubbins EJ, Bogorad L (1983) Nucleotide sequences of five maize chloroplast transfer RNA genes and their flanking regions. J Biol Chem 258:55035511

Taberlet P, Gielly L, Pautou G, Bouvet J (1991) Universal primers for amplification of three non-coding regions of chloroplast DNA. Pl Mol Biol 17:1105-1109

Tonkyn JC, Gruissem W (1993) Differential expression of the partially duplicated chloroplast S10 ribosomal protein operon. Mol Gen Genet 241:141-152

van Ham RCHJ, 't Hart H, Mes THM, Sandbrink JM (1994) Molecular evolution of noncoding regions of the chloroplast genome in the Crassulaceae and related species. Curr Genet 25:558-566

Vogel J, Hess WR (2001) Complete $5^{\prime}$ and $3^{\prime}$ end maturation of group II intron-containing tRNA precursors. RNA 7:285-292

Vogel J, Börner T, Hess WR (1999) Comparative analysis of splicing of the complete set of chloroplast group II introns in three higher plant mutants. Nucleic Acids Res 27:38663874

Wakasugi T, Tsudzuki J, Ito S, Nakashima K, Tsudzuki T, Sugiura M (1994) Loss of all $n d h$ genes as determined by sequencing the entire chloroplast genome of the black pine Pinus thunbergii. Proc Natl Acad Sci USA 91:9794-9798

Wang MJ, Davis NW, Gegenheimer P (1988) Novel mechanisms for maturation of chloroplast transfer RNA precursors. EMBO J 7:1567-1574

Wolfe KH, Morden CW, Ems SC, Palmer JD (1992) Rapid evolution of the plastid translation apparatus in a nonphotosynthetic plant: loss or accelerated sequence evolution of tRNA and ribosomal protein genes. J Mol Evol 35:304-317

Won H, Renner SS (2003) Horizontal gene transfer from flowering plants to Gnetum. Proc Natl Acad Sci USA 100:10824-10829

Won H, Renner SS (2005a) The internal transcribed spacer of nuclear ribosomal DNA in the gymnosperm Gnetum. Mol Phylogenet Evol 36 (in press)

Won H, Renner SS (2005b) Bayesian relaxed clock estimates suggest that the gymnosperm Gnetum (Gnetales) dispersed over water between South America, Africa and Asia (submitted for publication)

Wu C-Y, Lin C-H, Chen L-J (1997) Identification of the transcription site for the spinach chloroplast tRNA genes. FEBS Lett 418:157-161

Xu MQ, Kathe SD, Goodrich-Blair H, Nierzwicki-Bauer SA, Shub DA (1990) Science 250:1566-1570

Zaug AJ, McEvoy MM, Cech TR (1993) Self-splicing of the group I intron from Anabaena pre-tRNA: requirement for base-pairing of the exons in the anticodon stem. Biochemistry 32:7946-7953

Zuker M (2003) Mfold web server for nucleic acid folding and hybridization prediction. Nucleic Acids Res 31:3406-3415 
Table A1. Species sampled, vouchers, GenBank accession numbers, and summary for length (bp) and G $+\mathrm{C}(\%)$ content for chloroplast trnT-trnL IGS, trnL intron, and $\operatorname{trn} L$-trnF IGS sequences

\begin{tabular}{|c|c|c|c|c|c|}
\hline \multirow[b]{2}{*}{ Taxon } & \multirow[b]{2}{*}{ Voucher } & \multirow{2}{*}{$\begin{array}{l}\text { GenBank } \\
\text { accession No. }\end{array}$} & \multicolumn{3}{|c|}{ Length $(\mathrm{G}+\mathrm{C})$} \\
\hline & & & $\operatorname{trn} T-\operatorname{trn} L \mathrm{IGS}$ & $\operatorname{trn} L$ intron & $\operatorname{trn} L-\operatorname{trn} F$ IGS \\
\hline \multicolumn{6}{|l|}{ Gnetaceae } \\
\hline G. acutum & F. Markgraf Church et al. 284 (A) & AY296485 & $296(31.4)$ & $340(37.4)$ & $148(43.2)$ \\
\hline \multirow[t]{2}{*}{ G. africanum } & Welw. Essouma 99 (MO) & AY296486 & $292(31.5)$ & $384(34.9)$ & $165(37.0)$ \\
\hline & McPherson et al. 16261 (MO) & AY296487 & $292(31.2)$ & $384(34.9)$ & $165(37.0)$ \\
\hline G. costatum & K. Schum. Takeuchi et al. 15415 (MO) & AY296488 & $301(34.2)$ & $346(37.3)$ & $141(39.0)$ \\
\hline \multirow{2}{*}{ G. cuspidatum $\mathrm{Bl}$. } & Utami s.n. (BO) & AY296489 & $299(31.1)$ & $343(37.9)$ & $137(42.3)^{*}$ \\
\hline & Won 562 (MO) & AY296490 & $299(31.1)$ & $343(37.9)$ & $137(42.3)^{*}$ \\
\hline \multirow[t]{2}{*}{ G. diminutum } & $\begin{array}{l}\text { F. Markgraf Postar \& } \\
\text { Won SAN } 151122(\mathrm{MO})\end{array}$ & AY296491 & $299(31.1)$ & $344(37.2)$ & $140(42.9)^{*}$ \\
\hline & Postar \& Won SAN 151128 (MO) & AY296492 & $300(31.0)$ & $344(37.2)$ & $140(42.9)^{*}$ \\
\hline \multirow[t]{3}{*}{ G. gnemon $\mathrm{L}$. } & RBGE 19480122 (E) & AY296493 & $296(31.1)$ & $344(36.6)$ & $138(36.2)$ \\
\hline & Suksathan s.n. (QSB) & AY296494 & $296(31.1)$ & $345(37.1)$ & $138(36.2)$ \\
\hline & Won $514(\mathrm{MO})$ & AY296495 & $307(32.9)$ & $344(37.2)$ & $140(38.6)$ \\
\hline \multirow{2}{*}{ G. gnemonoides } & Brongn. Postar \& Won SAN151121 (MO) & AY296496 & $311(32.8)$ & $351(38.7)$ & $166(33.1)$ \\
\hline & Utami s.n. (BO) & AY296497 & $311(33.1)$ & $329(38.9)^{*}$ & $162(34.0)$ \\
\hline \multirow[t]{5}{*}{ G. hainanense s.l. } & RBGE 19550226 (E) & AY296498 & $320(31.9)$ & $338(39.3)$ & $137(43.8)$ \\
\hline & Won 555 (MO) & AY296499 & $320(31.9)$ & $338(38.6)$ & $137(43.8)$ \\
\hline & Won \& Maxwell 580 (MO) & AY296500 & $320(31.6)$ & $338(38.5)$ & $138(43.5)$ \\
\hline & Won \& Gang 600 (MO) & AY296501 & $320(31.9)$ & $340(38.5)$ & $138(44.9)$ \\
\hline & Jian s.n. (MO) & AY296502 & $320(31.9)$ & $338(38.5)$ & $137(43.8)$ \\
\hline \multirow[t]{2}{*}{ G. klossii } & $\begin{array}{l}\text { Merrill ex F. Markgraf Postar \& } \\
\text { Won SAN } 151117 \text { (MO) }\end{array}$ & AY296503 & $309(30.4)$ & $334(38.3)^{*}$ & $140(41.4)$ \\
\hline & Postar \& Won SAN 151124 (MO) & AY296504 & $309(30.4)$ & $334(38.3)^{*}$ & $140(41.4)$ \\
\hline \multirow{3}{*}{ G. latifolium Bl. s.l. } & Won $524(\mathrm{MO})$ & AY296505 & $320(31.6)$ & $338(38.2)$ & $142(42.3)$ \\
\hline & Won et al. 575 (MO) & AY296506 & $319(31.7)$ & $338(38.2)$ & $142(41.5)$ \\
\hline & Beaman et al. 9408 (MO) & AY296509 & $340(31.2)$ & $337(37.7)$ & $149(41.6)$ \\
\hline G. aff. latifolium & Won $545(\mathrm{MO})$ & AY296507 & $320(31.3)$ & $328(38.1)^{*}$ & $144(41.7)$ \\
\hline G. aff. latifolium & Postar \& Won SAN $151116(\mathrm{MO})$ & AY296508 & $320(31.6)$ & $339(38.1)$ & $145(42.1)$ \\
\hline G. macrostachyum & Hook. f. Won 535 (MO) & AY296511 & $300(31.7)$ & $338(38.2)^{*}$ & $144(43.1)$ \\
\hline \multirow[t]{2}{*}{ G. aff. Microcarpum $\mathrm{Bl}$. } & Won $526(\mathrm{MO})$ & AY296512 & $300(31.0)$ & $347(38.0)$ & $147(42.9)$ \\
\hline & Won 533 (MO) & AY 296513 & $299(31.1)$ & $346(37.3)$ & $147(43.5)$ \\
\hline G. microstachyum Benth. ex Tul. & Renske s.n. (U) & AY296514 & $304(32.6)$ & $329(35.6)$ & $132(43.9)$ \\
\hline G. neglectum $\mathrm{B} 1$. & Postar \& Won SAN151111 (MO) & AY296510 & $320(32.5)$ & $331(39.3)^{*}$ & $147(42.2)$ \\
\hline G. nodiflorum Brongn. & Gillespie 4246 (US) & AY296515 & $301(32.6)$ & $347(37.5)$ & $158(36.7)$ \\
\hline G. paniculatum Spruce ex Benth. & Aymard et al. 12208 (MO) & AY296516 & $301(32.2)$ & $379(34.8)$ & $154(38.3)$ \\
\hline G. parvifolium (Warb.) & Cheng ex Chun Won \& Gang 601 (MO) & AY296517 & $320(31.6)$ & $336(37.5)$ & $140(45.7)$ \\
\hline G. raya & F. Markgraf Kessler et al. $624(\mathrm{MO})$ & AY296518 & $302(32.1)$ & $342(39.2)$ & $160(39.4)$ \\
\hline \multicolumn{6}{|c|}{ G. aff. Schwackeanum Taub. ex } \\
\hline F. Markgraf & Won $512(\mathrm{MO})$ & AY296519 & $301(31.9)$ & $319(35.1)^{*}$ & $169(34.3)$ \\
\hline G. tenuifolium Ridl. & Carlquist 8087 (MO) & AY296520 & $300(31.3)$ & $343(36.4)$ & $141(41.8)$ \\
\hline G. ula Brongn. & Maheshwari s.n. (UCB) & AY296521 & $300(32.0)$ & $334(38.0)$ & $145(42.1)$ \\
\hline G. urens (Aubl.) Bl. & Prévost 4094 (MO) & AY296522 & $300(32.3)$ & $329(35.6)$ & $147(39.5)$ \\
\hline \multicolumn{6}{|c|}{ G. woodsonianum (F. Markgraf) } \\
\hline H. Won stat. nov. & Won 513 (MO) & AY296523 & $300(32.0)$ & $331(35.3)$ & $154(37.0)$ \\
\hline G. sp. Harder et al. 5621 & Harder et al. 5621 (MO) & AY296524 & $300(32.7)$ & $340(38.5)$ & $133(43.6)$ \\
\hline G. sp. (Vinkiella nom. nud.) & Takeuchi et al. 7049 (MO) & AY296525 & $300(32.0)$ & $332(37.4)$ & $140(40.0)$ \\
\hline \multicolumn{6}{|l|}{ Welwtischiaceae } \\
\hline Welwitschia & Olson s.n. (MO) & AY513733 & $313(30.4)$ & $317(37.4)$ & $250(33.2)$ \\
\hline \multicolumn{6}{|l|}{ Ephedraceae } \\
\hline Ephedra trifurca Torr. & Ickert-Bond SB753 (ASU) & AY513734 & $156(28.8)$ & $290(26.6)$ & - \\
\hline Ephedra torreyana Coville & Ickert-Bond SB941 (ASU) & AY513736 & $156(28.8)$ & $290(36.9)$ & - \\
\hline Ephedra viridis $\mathrm{S}$. Wats. & Ickert-Bond SB954 (ASU) & AY513735 & $156(28.8)$ & $290(37.2)$ & - \\
\hline
\end{tabular}

*Indicates incomplete sequence. 
Table A2. List of informative gaps in the Gnetum chloroplast tRNA ${ }^{\text {Leu }}$ intron and adjacent IGS regions: Base positions 142-181, 246-260, 297-301, 576-606, 706-745, 810-853, 976-993, and 1012-1070, which include these gaps, were excluded from the analyses

\begin{tabular}{|c|c|c|c|}
\hline Code & Location (bp) & Region & Distribution of indel \\
\hline A & $142-161$ & $\operatorname{trn} T-\operatorname{trn} L \mathrm{IGS}$ & $\begin{array}{l}\text { G. hainanense s.l., G. parvifolium, } \\
\text { G. latifolium s.l., G. neglectum }\end{array}$ \\
\hline B & $267-271$ & $\operatorname{trn} T-\operatorname{trn} L \mathrm{IGS}$ & G. africanum, S. American spp. \\
\hline $\mathrm{C}$ & $297-301$ & $\operatorname{trn} T-\operatorname{trn} L \mathrm{IGS}$ & G. gnemonoides, G. raya \\
\hline $\mathrm{D}$ & 364 & $\operatorname{trn} T-\operatorname{trn} L \mathrm{IGS}$ & S. American spp. \\
\hline $\mathrm{E}$ & $396-402$ & $\operatorname{trn} T-\operatorname{trn} L \mathrm{IGS}$ & $\begin{array}{l}\text { G. africanum, SE Asia clade I spp., } \\
\text { S. American spp. }\end{array}$ \\
\hline $\mathrm{F}$ & $662-670$ & $\operatorname{trn} L$ intron & $\begin{array}{l}\text { G. microstachyum, G. schwackeanum, } \\
\text { G. urens, G. woodsonianum }\end{array}$ \\
\hline G & $741-744$ & $\operatorname{trn} L$ intron & $\begin{array}{l}\text { G. acutum, G. cuspidatum, G. diminutum, } \\
\text { G. klossii, G. macrostachyum, } \\
\text { G. microcarpum, G. tenuifolium, } \\
\text { G. gnemon, G. costatum }\end{array}$ \\
\hline $\mathrm{H}$ & 749 & $\operatorname{trn} L$ intron & SE Asia clade I spp. \\
\hline I & $1056-1062$ & $\operatorname{trn} L-\operatorname{trn} F$ IGS & S. American spp. \\
\hline $\mathrm{J}$ & $1069-1070$ & $\operatorname{trn} L-\operatorname{trn} F \mathrm{IGS}$ & S. American spp. \\
\hline $\mathrm{K}$ & $1106-1113$ & $\operatorname{trn} L-\operatorname{trn} F \mathrm{IGS}$ & G. hainanense s.l., G. parvifolium \\
\hline
\end{tabular}

Table A3. Sequence divergences (K-2-P) for the cp $\operatorname{trn} L$ intron and adjacent IGS regions

\begin{tabular}{lrcr}
\hline & S. America & Africa & \multicolumn{1}{c}{ Asia I } \\
\hline trnL Intron & & & \\
S. America & $0-0.022$ & 0 & \\
Africa & $0.030-0.040$ & $0.024-0.045$ & 0.032 \\
Asia I & $0.026-0.057$ & $0.024-0.040$ & $0.018-0.045$ \\
Asia II & $0.022-0.062$ & & \\
trnT-trnL IGS & $0-0.017$ & & $0-0.076$ \\
S. America & $0.108-0.120$ & 0.003 & $0.014-0.092$ \\
Africa & $0.052-0.100$ & $0.083-0.124$ & \\
Asia I & $0.046-0.091$ & $0.078-0.123$ & \\
Asia II & $0-0.061$ & & $0-0.225$ \\
trnL-trnF IGS & $0.124-0.286$ & 0 & $0.024-0.137$ \\
S. America & $0.069-0.288$ & $0.082-0.257$ & \\
Africa & $0.048-0.114$ & $0.059-0.088$ & \\
Asia I & & & $0-0.046$ \\
Asia II & $0-0.023$ & 0.001 & \\
Total & $0.077-0.112$ & $0.060-0.106$ & $0.003-0.064$ \\
S. America & $0.047-0.106$ & $0.052-0.072$ & $0.023-0.070$ \\
Africa & $0.043-0.066$ & &
\end{tabular}

